\title{
Biogeochemical response of New \\ Caledonia lagoon sediments to tropical events: a numerical modeling approach
}

\author{
ERIC VIOLLIER $^{1}$, PAULINE MERROT ${ }^{2}$, OLIVIER \\ RADAKOVITCH ${ }^{3}$, GUILLAUME MORIN ${ }^{4}$, JEAN-MICHEL $^{2}$ \\ FERNANDEZ $^{5}$, BENJAMIN MORETON ${ }^{5}$, STANLEY I \\ $\mathrm{NMOR}^{6}$ AND FARID JUILLOT ${ }^{7}$ \\ ${ }^{1}$ LSCE CNRS \\ ${ }^{2}$ UMR CNRS 5805 EPOC - OASU \\ ${ }^{3}$ IRSN \\ ${ }^{4}$ Institut de Minéralogie, de Physique des Matériaux et de \\ Cosmochimie (IMPMC), UMR 7590 Sorbonne Université- \\ CNRS-MNHN-IRD \\ ${ }^{5}$ AEL Environnement \\ ${ }^{6}$ LSCE/CNRS CEA UVSQ University Paris-Saclay \\ ${ }^{7}$ ERL IRD 206, UMR 7590 CNRS-MNHN-Sorbonne Université \\ Presenting Author: eric.viollier@1sce.ipsl.fr
}

New Caledonia main island is made of ultramafic rocks largely covered by metal-rich laterites. Mining activity enhances erosion and detrital deposit to the lagoon coastline. This anthropogenic process is itself enhanced by tropical cyclones. This numerical work explores long term early diagenesis processes, especially the formation of authigenic minerals such iron sulfides and "green clays" in shallow sediment. As well, the short term biogeochemical response is investigated regarding different scenarios: a massive sediment deposit due to river flooding and sediment resuspension events. Modeling outputs are compared to results obtained in 2016 and 2018 from campaigns at sea in the Northwest of New Caledonia. 